need they doubt but that at some far distant date the human race might at length make its way on through those regions too, and attain, even by that apparently arid path, the rich tropical belt of luxurious verdure and bright sunshine where conflict ceased and art and enjoyment and emotion and rcligion began. Facts known to few with effort were science, but those same facts when known to all without effort were iesthetic; they could then be appreciated in a fuller and higher way, crould be seen in an altogether new light, so that they became fit subjects for poetry, for music, and for art.

Meanwhile, the justification of all pure, dry science lay essentially in its ultimately human bearings. If a subject could be proved to be never capable of any human influence or any relation to humanity, however developed it might become, then its pursuit would be rightly condemned. But such proof could never be given. Again and again had the most unlikely channels developed into fruitful watercourses. We must trus the instinct of our leaders and let them advance unhampered, in the faith that where they felt so much enthusiasm, where they scemed to see their way so clearly and so well, we too, in time or our descendants, should be able to enter with their aid, and should realise that the remote and at first sight hopelessly in accessible region was full, after all, of human interest, and of that which contributed to the enrichment of life.

Referring to the present state of electrical knowledge, Dr. Lodge spoke as follows :-

"We are in the beginning of a great era in connection with the pure science of electricity. The almost despised and neg lected subject of electrostatics, as known to Franklin, is rearing its head again and pressing to the front.

"The experiment of a charged rod and pith balls is typical of much, perhaps typical of all that goes on in electricity; and how much this means some of us are beginning to guess. It is to the works of Larmor and the late Prof. Fitzgerald that we must look for an explanation of the nature of an electric charge -that blank, that absolute void so wisely left by Clerk Maxwell in his scheme, and by Helmholt\% in his - a void occupied only by the isolated brilliant surmise contained in the phrase 'one molecule or atom of electricity.'

"But even before we understand the nature of an electric charge we shall find that the labours of J. J. Thomson have enriched the science of our times with what appears likely to be a unifying and comprehensive generalisation such as philosuphers of all time have groped after, for which some of them have strongly hoped."

Concluding his address, Dr. Lodge illustrated with a few simple experiments the most recent views of the nature of the electric current. The atom was ordinarily associated with a charge, and force was required to separate them. This atomic charge, when separated, was known as an electron.

In the electrolyte there was a bodily transfer of atoms with their atomic charges.

In a metallic conductor the charges were handed on as electrons from atom to atom.

But it was in the discharge through highly rarefied gases that the electric current was in its most simple form, for here there was a flow of electrons travelling by themselves, of disembodied charges or electric ghosts. It was interesting to notice that. with their enormous speed of one-tenth of that of light-wave propagation, these electrons were the fastest moving of all known terrestrial objects.

A revolving electron was a magnet. A vibrating one could start light vibrations. And it might even be that inertia itself --that familiar but unexplained property of matter-was but elictromagnetic inertia in disguise.

Prof. Perry, in thanking the chairman for his address, remarked that the country was now very much alive to the need for improvement in the scientific education of practical men. All the scientific world was watching to see what Dr. Lodge was going 10 make of the great problem that was before him of the Birmingham University.

He deprecated the tendency in this Institution to array professors and engineers against one another, and advocated the culivation of a spirit of mutual helpfulness as between men whose various endowments must be interdependent if they were to he fully utilised.

I'rof. Perry congratulated the new local section on its suc cessful start and on its locality, saying that the people of Birmingham were very early in introducing scientific methods of manufacture. The stress of international competition called for

No. 1636 , VOL, 63] the greatest ar-ivily in scientific methods in all our centres. The Institution of Electrical F.ngineers was doing a great work and had a great future before it in tinding together the best thinkers in a great association for the conimon good.

Prof. Threlfall seconded the motion, and the meeting con cluded with a feeling reference to the untimely death of Prof. G. F. FitzGerald, who was chairman of the Dublin local section of the Institution.

\section{THE TAMNAU MINERALOGICAL ENDOWWENT.}

I $N$ the year 1879 occurred the death of I)r. Friedrich Tamnau, 1 . a rich Berlin banker, who was also an enthusiastic collector of minerals; his collection was well known, and was frequently used by mineralogists; a considerable portion of it was given to the Berlin Museum during his life-time, and at his death the remainder was bequeathed to the technische Hochschule at Charlottenburg.

Dr. Tamnau's services to the science of mineralngy did not end with his death. He left to the University of Berlin a sum of 36,000 marks for the purpose of founding a mineralogical travelling fund.

By the stalutes of the founder it is enacted that when the fund has accumulated to a sufficient extent it shall be employed in sending away a young and promising mineralogist to some interesting locality, in order to stucly the modes of occurrence of fine or rare minerals, to collect, and to report upon them. It is expressly stipulated that the fund is to be applied to mineral. ogical, not geological, purposes. The specimens are to go in the first instance to the Berlin University collection, then to the technische Iochschule, but they may also be given or exchanged to other collections. The administration of the fund is in the hands of three trustees; those named by the founder to hold office at the beginning were Profs. von Rath, of Bonn, Groth, of Strassburg, and Websky, of Berlin.

The first application of the Tamnau fund was made in sending Dr. Tenne, of Berlin, on a successful mineralogical tour in southern Spain.

Two of the original trustees are dead, and the fund is now administered by Profs. (iroth, of Mfunich, Klein, of Berlin, and Bauer, of Marburg.

The second award, 10,000 marks, was made in 1896. Dr. F. Grunling, the well-known assistant of Prof. Groth, first at Strassburg and subsequently at Munich, and now curator of the State collection of minerals in Munich, was commissioned to undertake a mineralogical expedition in Ceylon.

The valuable results of Dr. Griinling's tour have now been published. A triple Ileft (Nos. 3-5) of the thirty-third volume of Groth's Zeilschrift fïr K'y'stallographie und Mineralogie is almost entirely occupied by the scientific work done upon the material which was brough: buck from Ceylon, and those who wish to see the excellent results of a wise scientific endowment wisely administered cannot do better than glance over this publication.

Dr. Grinling brought back rich collections, especially of the dolomite and the minerals which it contains, of the graphite and of the gem-stones; among the latter the most remarkable are the tourmalines, which constitute a unique series of beautiful crystals.

All these minerals have now been examined by various workers in Prof. (Groth's laboratory. The graphite has been the subject of exhaustive study by Dr. Weinschenk, the lecturer on petrclogy in the University of Munich, who has already published papers on the subject in the Zeitschrife fiir Praktis he Geologie and in the Abhanillungen of the Bavarian Academy of Sciences. The dolomite has been analysed by Dr. Schiffer, whose results have been given as an inaugural dissertation. And now has appeared this triple Heft of Groth's Zeitschrift, containing a general description of Ceylon and its minerals by Dr. Grünling, a research upon the chrysoberyl, the sillimanite and the blue spinel by Ir. Melczer, and a voluminous report upon the tourmaline crystals by 1)r. Worobieff, whose memoir occupies nearly 2 co pages, and is in reality a crystallographic monograph of the mineral

The fact that so much has been achieved will suggest to the reader that the collection and scientific study of Ceylon minerals has been sadly neglected by our own countrymen. A perusal of Dr. Griinling's paper serves but to strengthen this conviction. 
With the exception of an interesting paper on the graphite and rocks of Ceylon, contributed last June to the Geological Society of London by Mr. Coomara-Swámy, but published too late to be alluded to by Dr. Grinling, little has been done. Mr. Coomára-Swámy himself remarks, "No geological survey is in progress in Ceylon; it is much to be hoped that the Government will soon realise the importance of instituting one."

To give a very brief survey of the scientific results :-

Dr. Grünling makes it clear that the graphite always occurs in typical symmetrical veins, though these have been much crushed and altered by earth movements which have spent their energy upon the soft graphite, and have consequently spared the country rock (granulite). Dr. Weinschenk comes to the conclusion that the graphite is of volcanic, and certainly not of organic origin, and is probably due to the action of vapours con. taining carbon; he suggests that carbon dioxide and cyanogen compounds have played the chief part in its production. Among the associated minerals it is remarkable that, as at Passau, nontronite is one of the invariable decomposition products accompanying the graphite.

Dr. Grinling is of opinion that the gemstones of the sands and gravels were derived from the dolomitic limestone which abounds in some parts of the island, for the spinel, which is certainly found in the limestone, contains sapphire, phlogopite, $\& c$., while the corundum contains phlogopite, rutile and spinel. A granular marble from Wattegama, on the Kandy railroad, proves to be a theoretically pure dolomite; it contains, among other minerals, a remarkable blue apatite, which has been analysed by Dr. Schiffer and is found to be a fuor-apatite containing 15 per cent. of chlor-apatite. It is curious that Dr. Grünling was unable to obtain any information concerning the original locality of the tourmalines; they are probably all derived from the cabook or laterite, and from some one place.

Worobieff's crystallographic measurements relate to I Io crystals remarkably rich in faces, and have resulted in the establishment of no less than $13 \mathrm{I}$ new forms; one crystal alone presented the faces of fifty-nine forms; the table of calculated angles fills fortythree pages. He finds that the symmetry of tourmaline is undoubtedly ditrigonal, and not tetartohedral as has been supposed by some authors. The paper also contains numerous observations upon the pyro-electric properties of tourmaline, and distinguishes between the faces of the analogous and of the antilogous poles.

Dr. Melczer's paper establishes beyond doubt that the chrysoberyls of Ceylon, of Brazil and of the Urals (Alexandrite) posress the same axes, and that the twinning takes place parallel to (03I), not to (OrI). His optical study of the spinel leads him to the conclusion that the refractive index of this mineral varies with the colour ; it is least in the most highly coloured parts.

The whole series of investigations reflects much credit upon the administration of the Tamnau fund, upon those who have collected and studied the minerals, and upon Prof. Groth, in whose laboratory the investigations have been successfully carried out.

The next award of this useful fund will be expected with interest.

I. A. MiERs.

\section{CRANIOLOGY.}

WE have assembled here to-day in order that we may com. memorate the merits of John Hunter and such other persons whose labours have contributed to the extension of our knowledge in comparative anatomy, physiology, or surgery. Hunter's life in all its various aspects has been so frequently dwelt on in former orations delivered in this theatre that it is beyond my power to throw any tresh light on this subject. His fame is attributable to his having possessed an intense love of science, indomitable energy, and a self-reliant, manly character. If we turn to his portrait hanging on the walls of this theatre, it would seem that at the time when this likeness was painted Hunter was engaged in the study of the craniology of man and anthropoid apes, for on the table before him there is an open volume, and on its pages we see clearly drawn a human skull and the skull of a chimpanzee. Hunter is portrayed, pen in hand, in deep thought, having just turned away from the bouk he had been

1 "The Hunterian Oration." Delivered in the theatre of the Royal College of Surgeons of England on February ${ }_{4}$, by Mr. N. C. Macnamara. Abridged from the Lancet. studying, and though his notes on comparative anatomy were unfortunately destroyed with his other manuscripts, we can hardly doubt that craniology was a subject in which he was deeply interested, or it would not have held so prominent a position in this famous picture. It would, therefore, seem that on an occasion such as the present we can do no higher honour to Hunter's memory and to that of some of the able men of science who have followed him than by endeavouring to give in as few words as possible a risume of their labours, with especial reference to the subject of craniology and the light it is capable of throwing on the prehistoric inhabitants of western Europe and of the evolution of the race of men to which we beiong. One of the most brilliant and original thinkers who has occupied the presidential chair of this college, Sir William Lawrence, in his ever-memorable lectures on the natural history of man, delivered in this college in the year 1819 , from his re. searches in comparative anatomy, foreshadowed the idea that man and apes were derived from common ancestors. Lawrence's opinions were received with a storm of adverse criticism. Mr. Abernethy, for instance, charged him with "propagating opinions detrimental to society and endeavouring to enforce them for the purpose of loosening those restraints on which the welfare of mankind depend." Time, however, has proved that Lawrence was right, and in the course of lectures delivered in this theatre in February I 899 , Prof. Keith, from a careful analysis of the maximum number of anatomical characters common 10 man and apes, arrived at the conclusion that they are derived from an identical or a kindred stock. While adnitting without reserve that man and apes are structurally almost identical, nevertheless, as pointed out by Prof. Huxley in the year 1863 , they differ very materially as regards the relative weight of their brains. The carcass of a full-grown gorilla is heavier than that of an average sized European, but it is doubtful whether a healthy adult European's brain ever weighed less than 32 ounces, or the brain of the heaviest gorilla ever exceeded 20 ounces in weight. Although at the present time there is this marked relative difference between the weight of the brain and the form of the skulls of Europeans and apes, this was not always the case, for the calvaria of the earliest discovered human beings were in form not very far removed from those of contemporary anthro. poid apes. This fact leads us to inquire into the nature of the conditions which have led to the increased capacity of the human cranium and to the vast superiority of man's intellectual endowments over those of all the other primates. If we turn to Hunter's preparations in our museum we find among them some remarkable specimens which he describes as "com. pressed," "unsymmetrical " human crania, which he believed were the result of premature consolidation of one or more of the sutures of the skull. Since IIunter's day various authorities have devoted much time to the subject of the abnormal closure of the cranial sutures in man; prominent among them are the names of the chief of England's craniologists, Dr. Thurnam and Dr. Barnard I)avis-the splendid collection of prehistoric and other skulls made by the latter gentleman are now in the possession of our college. From evidence of this nature we have come to learn that the size and form of the skull depends to a large extent on the growth of the bones of which it is formed along the lines of the various cranial sutures.

It is well known that the frontal bone, which forms the vault of the anterior part of the cranium in the young of man and apes, is divided by a suture, and so long as this line of growth, together with the coronal and other sutures by which the frontal is separated from surrounding bones, remains open, the fore part of the skull, and with it the anterior fussie which it encloses, can expand. But if the frontal and the other anterior sutures of the cranium consolidate early in life the fore part of the skull cannot increase in capacity beyond the size it had reached in infancy. Prof. Deneker, in his work on the embryology and development of anthropoid apes, has shown that in consequence of the early closure of the anterior sutures of the skull of these animals the fore part of their brain does not increase beyond the size it had attained at the end of the first year of life, but in man these sutures do not consolidate until a much later period, so that the anterior lobes of his brain are enabled to, and actually dn, become far more perfectly developed than the corresponding lobes among apes; men of the same bulk have four times as much superficial brain surface as anthropoid apes.

Whatever other functions the anterior lobes of the brain perform, their cortical nerve elements, in conjunction with

NO. I6 36 , VOL. 63] 